\title{
SOLVING THE CONUNDRUM OF JOB
}

\section{A probable biblical description of chronic renal failure with neurological symptoms}

\author{
Luiz Antonio de Lima Resende', Daniel Rocco Kirchner', Lucilene Silva Ruiz e Resende ${ }^{2}$
}

\begin{abstract}
The disease described in the Bible's Book of Job is controversial and had been of interest of theologists, psychiatrists, and dermatologists for many years. We describe several signs and symptoms compatible with chronic renal failure with neurological alterations.
\end{abstract}

KEY WORDS: bible, Job, chronic renal failure.

\section{Resolvendo o enigma de Jó: uma provável descrição bíblica de insuficiência renal crônica com sintomas neurológicos}

Resumo - A doença descrita no livro bíblico de Jó é controversa, e tem interessado a teólogos, psiquiatras e dermatologistas, há tempos. Neste trabalho os autores apontam para evidências do diagnóstico de insuficiência renal crônica com alterações neurológicas.

PALAVRAS-CHAVE: bíblia, Jó, insuficiência renal crônica.

Important figures in world history developed chronic renal failure. Mozart had frequent attacks of tonsillitis during his life, developing consequent post-streptococcal Henoch-Schönlein syndrome and chronic glomerular nephritis. He probably died from chronic renal failure ${ }^{1}$, and the description of his disease is one of the oldest documents in the history of the chronic uremia.

In our opinion, the Book of Job in the Bible, which was written between 600 and $300 \mathrm{BC}^{2}$, describes signs and symptoms compatible with chronic renal failure.

The purpose of this paper is to review the clinical picture described in Job's book with special emphasis on the neurological signs and symptoms. We believe this would be the oldest description of chronic renal failure.

\section{METHOD}

The first author had collected documents of the history of chronic renal failure since the first published paper about neurological compromise in this disease $e^{3}$. We have described the oldest documents of the Book of Job, from the English Bible ${ }^{4}$, related to signs and symptoms of chronic uremia. The English version of the Holy Bible was compared to original translations made by Martin Luther, in German ${ }^{5}$. To solve translation doubts or linguistic discrepancies we made translations from the Greek Septuagint $a^{6}$. The revised translations are presented in both English and German.

At the end of the Results section we have included some old prints which depict the Book of Job story (Figure) ${ }^{7-10}$.

\section{RESULTS}

We were able to find many different symptoms which are probable related to chronic renal failure:

a) General signs and symptoms compatible with the clinical spectrum for chronic renal failure described in the Book of Job:

a.1) Pruritus: ...And he (Job) took a potsherd with which to scrape himself... Job 2:8.

a.2) Uremic frost (?):...God has cast me into the mire, and I have become like dust and ashes... Job 30:19. ...geachtet dem Staub und der Asche (Job 30:19).

a.3) Ictiosis (?):...my skin hardens... Job 7:5.... have sewed sackcloth upon my skin... Job 16:15.

a.4) Others: ...My face is red with weeping, and on my eyelids is deep darkness... Job 16:16. ... a flood of water

\footnotetext{
'Member of the Department of History of Neurology of the Brazilian Academy of Neurology; 'Departments of Neurology, Psychology and Psychiatry, and Internal Medicine ${ }^{2}$, Botucatu School of Medicine, São Paulo State University, UNESP, São Paulo SP, Brazil.
}

Received 2 October 2008, received in final form 3 February 2009. Accepted 23 April 2009.

Dr. Luiz Antonio de Lima Resende - Department of Neurology and Psychiatry / Botucatu School of Medicine - 18618-970 Botucatu SP - Brasil. E-mail: luanlire@hotmail.com 
covers you (Job)... Job: 22:11. ... His strength (of Job) is hunger-bitten...Job 18:12....shuddering seizes my flesh... Job 21:6.

b) Symptoms compatible with visual hallucinations: When I say, "My bed will comfort me, my couch will ease my complaint", then thou dost scare me with dreams and terrify me with visions... Job 7:13-14;

c) Symptoms compatible with visual alterations (blindness? uremic amaurosis? hemianopsis?): ...your light is darkened, so that you cannot see ... Job 22:11. ... he passes by me, and I see him not; he moves on, but I do not perceive him... Job 9:11; ...on the left hand I seek him, but I cannot behold him; I turn to the right hand, but I cannot see him... Job 23:9; ...thick darkness covers my face. Job 23:17. ...I go about blackened, but not by the sun... Job 30:28.

d) Sleep disturbances: ... When I lie down I say, "When shall I arise?" But the night is long, and I am full of tossing till the dawn... Job 7:4.

e) Restlessleg syndrome (?): ...The night racks my bones, and the pain that gnaws me takes no rest... Job 30:17. Des Nachts wird mein Gebein durchbohrt allenthalben; und die mich nagen, legen sich nicht schlafen (Job 30:17).

f) Psychical alterations: ...for they saw that his suffering was very great. Job 2:13. ... I am not at ease, nor am I quiet; I have no rest; but trouble comes... Job 3:26. ...And now my soul is poured out within me; days of affliction have taken hold of me... Job 30:16.... My heart is in turmoil, and is never still; days of affliction come to meet me... Job 30:27. ...I have made a covenant with my eyes; how then could I look upon a virgin? Job 31:1. Ich habe einen Bund gemacht mit meinen Augen, dass ich nicht achtete auf eine Jungfrau (Job 31:1) ...As for you, you whitewash with lies; worthless physicians are you all... Job 13:4.

g) Symptoms compatible with peripheral neuropathy: g.1) Emaciation or muscle atrophies: ... and my leanness has risen up against me ... Job 16:8. ....My bones cleave to my skin and to my flesh... Job 19:20.... His flesh is so wasted away that it cannot be seen; and his bones which were not seen stick out... Job 33:21.

g.2) Pain, paresthesia or dysesthesias: ...I would even exult in pain unsparing... Job 6:10. ....My skin turns black and falls from me, and my bones burn with heat... Job 30:30.... Man is also chastened with pain upon his bed, and with continual strife in his bones... Job 33:19.

g.3) Hipoesthesia (?): ... my members are like a shadow... Job 17:7 ...und alle meine Glieder sind wie ein Schatten (17:7) h) Digestive symptoms:

h.1) Vomits: ... He slashes open my kidneys, and does not spare; he pours out my gall on the ground... Job 16:13.

h.2) Poor appetite: ...so that his life loathes bread, and his appetite dainty food... Job 33:20.

h.3) Halitosis (uremic breath ?): ... am repulsive to my wife, loathsome to the sons of my own mother... Job 19:17. ... Mein Odem ist zuwider meinem Weibe, und ich bin ein Ekel den Kindern meines Leibes (Job 19:17).

i) Use of hiponatremic diet: ...Can that which is tasteless be eaten without salt, or is there any taste in the slime of the purslaine? My appetite refuses to touch them; they are as food that is loathsome to me ...Job 6:6-7. ... Kann man auch essen, was ungesalzen ist? (Job 6:6)

\section{DISCUSSION}

The Book of Job had been of interest for many physicians from different parts of the world, especially from areas of Psychiatry, Psychoanalysis ${ }^{11-14}$, medical philosophy, and ethics ${ }^{15,16}$.

In the last 60 years dermatologists had proposed different diagnoses for Job's cutaneous syndrome, mainly pellagra ${ }^{17}$, leprosy, syphilis, variola ${ }^{18}$, and eosinophilic syndrome $^{19}$. Pemphigus foliaceus was also proposed ${ }^{20}$. Another hypothesis was malignant cancer or elephantiasis ${ }^{21}$. The cutaneous alterations seen in Albrecht Dürer's painting of Job (Figure) are probably influenced by the plague in Germany at that time ${ }^{7}$. In our opinion the most complete attempt to diagnose Job was made by Gorman and Kaplan ${ }^{22}$. They separated signs from symptoms, and argued that several of the signs and symptoms from Job syndrome were compatible with arsenic poisoning. However, this conclusion in not in accordance to our results. The cutaneous alterations described in the Book of Job are unespecific and may occur during the course of several diseases. Skin alterations from chronic renal failure such as hyperpigmentation, pruritus, dryness and flakness, and possible eyelid echymosis from uremia are described in our Results (a). General pruritus and possibly "uremic frost" are characteristic of uremia. Several descriptions of Job's "darkened skin" may correspond to hemorrhagic diathesis caused by defective platelet function in uremic patients. The "flood of water covering Job"..., his change in strength, and the "shuddering seizes of his flesh" may correspond to electrolyte disorders seen in uremia ${ }^{23-25}$.

There is clinical evidence that Job was a depressive (kapusta); his depression has been represented in paintings (Figure). Although depression is frequent in uremia, the probable visual hallucinations and loss of sight $(b$ and $c$ in results) suggest an organic cause of psychiatric disturbances ${ }^{26}$. The so called "uremic amaurosis" is an acute loss of vision in uremic patients. Recovery usually takes 


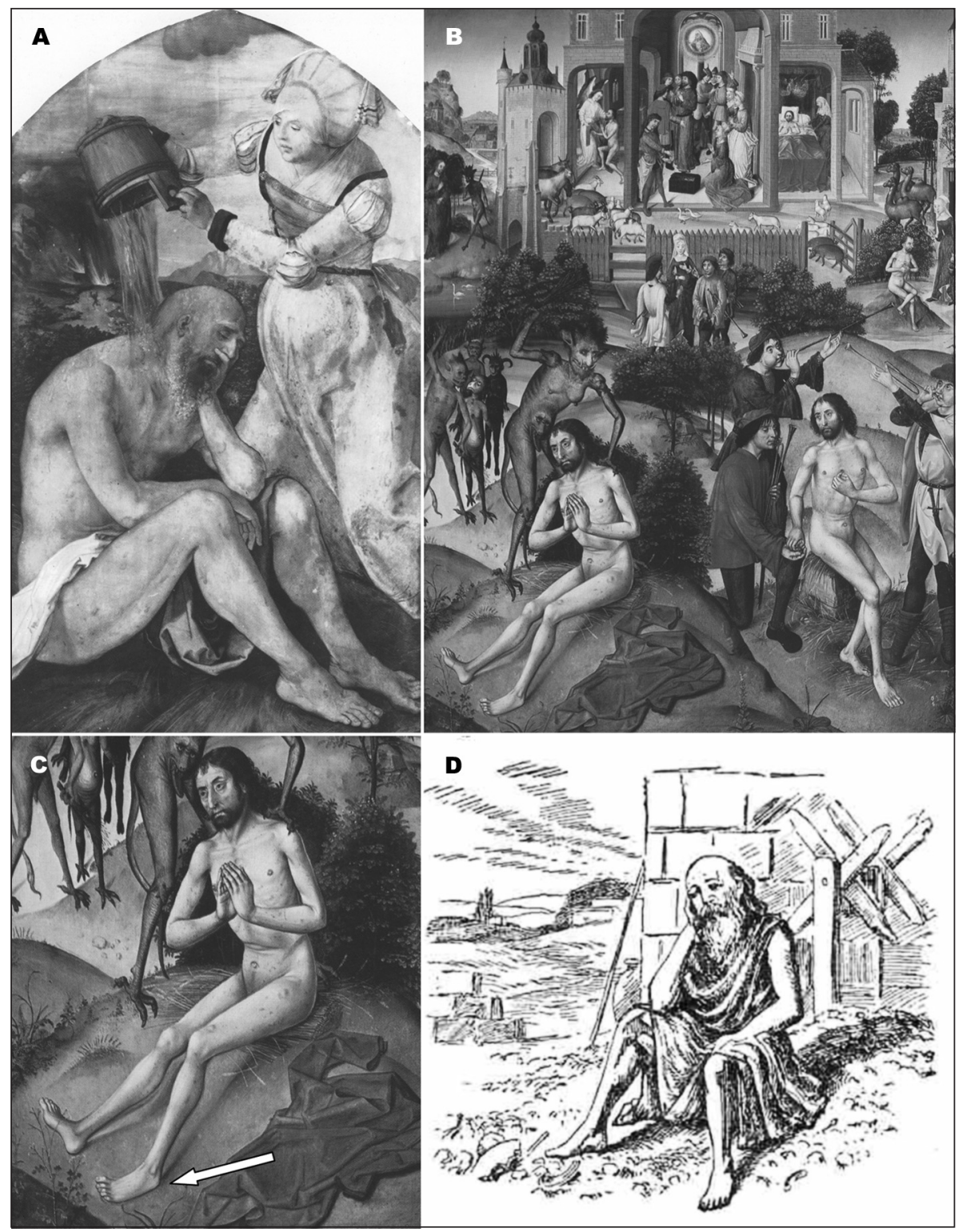

Figure. [A] Job and his Wife, oil on canvas, Albrecht Dürer, 1503-1504, Städelsches Kunstinstitut, Frankfurt, Germany. Job was shown in a depressive state with cutaneous lesions, probably from the plague at that time. [B] Altar, unknown author, 1480-1482, currently at the Wallraf-Richartz Museum, Köln, Germany. The painting represents a South German catholic legend where Job's cutaneous wounds transform into gold coins which are used to pay musicians ${ }^{8}$. The legend's origin is from the catholic title "Job - Patron of music and musicians". [C] Detail (of B). Job's left foot is presented with clawing toes in the equinovarus position - personal observation [D] Job represented as a depressive ${ }^{10}$.

place within hours to a few days ${ }^{26}$, and it was probably described by Job (result c). Anxiety, irritability, and psychosis are also frequent in uremic patients, and Job presented some of these symptoms (result $\mathrm{f}$ ). Sexual abnormality, a part of uremic syndrome, was also partially described by Job (result f).

Sleep disturbances ${ }^{27}$ and probable restless leg syndrome ( $\mathrm{d}$ and e) described in the Book of Job are frequent in uremic patients, as symptoms compatible with peripheral neuropathy, mainly the "positive symptoms" (result g.2 $)^{28}$.
The digestive symptoms as vomiting, poor appetite, and halitosis (results h.1, h.2, h.3) described by Job are frequent and cardinal digestive alterations found in uremic syndrome ${ }^{23,24}$. Halitosis was clear in Martin Luther's translation (Mein Odem = my breath, or my respiration, became offensive - repulsive to my wife) and was emphasized in Job because he became "repulsive to his wife and brothers" (result h.3).

Job's description ...My heart is in turmoil, and is never still, days of affliction come to meet me (Job 30:27) was in- 
cluded in the psychical alterations, but it possibly corresponded to the cardiovascular abnormalities and hypertension found in uremic syndrome. We have some doubts about this, but probably Job described the first hyponatremic diet in history (Job 6:6-7, i).

From the above considerations, we can add other findings to the previously described cutaneous Job syndrome; these are: visual hallucinations, loss of vision, sleep disturbances, restless leg syndrome, psychical alterations, possible peripheral neuropathy, vomiting, poor appetite, halitosis, the two common signs of uremia - uremic frost and pruritus, and the use of a hyponatremic diet. We therefore wish to contribute to solving the Job conundrum: for us Job had chronic renal failure with neurological alterations.

ACKNOWLEDGEMENTS - The authors wish to thank Rev. Mrs Grietje Couperius, of Botucatu Independent Presbyterian Church and Masters in Theology from Groningen University (The Netherlands), for her assistence with the Book of Job and for the Septuaginta translations.

\section{REFERENCES}

1. Davies PJ. Mozart's illnesses and death. J Royal Soc Med 1983; 76:776-785

2. Shedd RP. O Novo comentário da bíblia. $3^{\mathrm{a}}$ ed., São Paulo: Vida Nova, 1997:465.

3. Resende LAL, Speciali JG. Electroencephalogram before and after hemodialysis, peritoneal dialysis and renal transplantation: study of correlations between background activity and plasma biochemistry. Arq Neuropsiquiatr 1987:45:248-260.

4. Bible: Revised standard version, $2^{\text {nd }}$ ed, Bible Society - Stonehill Green: Swindon, 1971.

5. Die Bibel. Die ganze Heilige Schrift des alten un neuen Testaments. Amerikanischen Bibel-Gesellschaft, 1885. Die Bibel. Lutherbibel 1912. http:/ / www.bibel-online.net/buch/18. hiob/19.htlm\#19,17.

6. Brenton LCL. The Septuagint with apochypha: greek and english. Hendrickson: Peabody, 1987:665-698.

7. Friedman M. Bilder zur Bibel. Altes testament. Poseidon Press: Wien, 1985:103.

8. Friedman M. Bilder zur Bibel. Altes testament. Poseidon Press: Wien, 1985:113.

9. Meyer K. St. Job as a patron of music. The Art Bulletin 1954; 36:21-31.
10. Bihn M, Bealings J. The bible in pictures. The new bible symbols - old testament. The afflictions of Job. John A. Hartel: London, 1922:487.

11. Achenbaum WA, Orwoll L. Becoming wise: a psycho-gerontological interpretation of the book of Job. Int J Aging Hum Dev 1991;32:21-39.

12. Renik O. The biblical book of Job: advice to clinicians. Psychoanal Q 1991;60:596-606.

13. De Masi F. Intimidation at the helm: superego and hallucinations in the analytic treatment of a psychosis. Int J Psychoanal 1997;78:561-576.

14. Kapusta MA, Frank S. The book of Job and the modern view of depression. Ann Int Med 1977;86:667-672.

15. Lederman MM. Aids and the conundrum of Job. Am J Med 1992;92:679-680.

16. Kutz H. Job and his "doctors": bedside wisdom in the book of Job. BMJ 2000;321:1613-1615.

17. Brim CJ. Job's illness: pellagra. Arch Dermatol Syphilol 1942; 45:371-376.

18. Rosner F. Julius Preuss' biblical and talmudic medicine. New York: Hebrew Publishing Company, 1983:339-341.

19. Davis SD, Schaller J, Wedgwood RJ. Job's syndrome. Recurrent "cold" staphylococcal abscesses. Lancet 1966;1:1013-1015.

20. Hartley JE. The Book of Job. Eerdmans: Grand Rapids, 1988:82.

21. Adeyemo T. Africa bible commntary. Zondervan: Nairobi, 2006:573.

22. Gorman S, Kaplan DL. The affliction of Job: poisoned! J Am Acad Dermatol. 1999;40:126-128.

23. Benseñor IM, Atta JA, Martins MA. Semiologia clínica. Sarvier: São Paulo, 2002:604.

24. Prado FC, Ramos J, Valle JR. Atualização terapéutica . $23^{\mathrm{a}}$ ed., Artes Médicas: São Paulo, 2007:959.

25. Warnock DG. Chronic renal failure. In Bennet JC, Plum F (Eds). Cecil textbook of medicine. $20^{\text {th }}$ ed, Philadelphia: Saunders, 1996:556-559.

26. Tyler HR. Neurologic disorders in renal failure. Am J Med 1968;44:734-747.

27. Weisser A. Das Buch Hiob. Vandenhoeck and Huprecht: Göttingen, 1963:35.

28. Asbury AK. Neuropathies with renal failure, hepatic disorders, chronic respiratory insufficiency, and critical illness. In Dyck PJ, Thomas PK, Griffin JW, Low PA, Poduslo JF (Eds). Peripheral neuropathy. $3^{\text {rd }}$ ed, Saunders: Philadelphia, 1993: 1252-1253. 